\title{
Industrial Disputes at Ready Made Garments in Bangladesh: An Analysis
}

\author{
Mohammad Monir Hossen ${ }^{1}$, Md. Hossen Miazee ${ }^{2}$ \\ ${ }^{1}$ Department of Law, Z. H. Sikder University of Science and Technology, Shariatpur, Bangladesh \\ ${ }^{2}$ Depatment of Business Studies, University of Information Technology \& Sciences, Dhaka, Bangladesh
}

Email address:

monir_law@yahoo.com (M. M. Hossen),m.miazee@yahoo.com (M. H. Miazee)

\section{To cite this article:}

Mohammad Monir Hossen, Md. Hossen Miazee. Industrial Disputes at Ready Made Garments in Bangladesh: An Analysis. International Journal of Business and Economics Research. Vol. 5, No. 6, 2016, pp. 210-216. doi: 10.11648/j.ijber.20160506.14

Received: October 4, 2016; Accepted: October 28, 2016; Published: November 23, 2016

\begin{abstract}
The Ready Made Garments of Bangladesh at present occupy a rigid position in the national economy of Bangladesh. The sector has emerged with silent revolution, contributing economic development such as creating enormous employment, strengthening national GDP, decreasing child marriage, self- development through empowering women specially for the less privileged women. The sector exports various items with good quality and a good quantity throughout the world according to buyer's demand. Hence, the prospects and possibilities of the sector are increasing day by day. But some unexpected impediments created by some owners of the industry, political instability, politicizing the industrial disputes by the local politicians, non co-operation from the part of the leaders of CBA and trade unions, which ultimately undermine the image of the sector and jeopardizes the economy of the country. The study has taken an attempt to identify the reasons for industrial disputes occurred throughout the country. Some reported incidents have been mentioned in this regard. The paper is also suggesting to the concerned authority to take the effective step and materialize the proposals which are proposed in the study at the end.
\end{abstract}

Keywords: RMG, Industry, Garments, Disputes, Labour, Trade Union

\section{Introduction}

The RMG industry has been treated as the backbone of the economic development of Bangladesh. The tag "Made in Bangladesh" has also brought glory and honour to the country. The other countries are following Bangladesh as a role model, where it was given titled as "bottomless basket" [1] and now become a "basket full of wonders." Once upon a time the lone export earner of Bangladesh was the jute industry and golden fiber has lost its golden days, it is the RMG sector that took place in the jute industry. The readymade garment industry (RMG) in Bangladesh with 30 years of experience has turned into a sourcing hub in the global marketplace. RMG industries demonstrated a spectacular growth in exports over the past two decades [2]. The industry earns US\$ 624.16 million in 1989/90; US\$ 12496.72 million at the end of $2009 / 10$ and in 2012-13 it was USD 21515.73 million in terms of $81.71 \%$. In the last financial year, it was USD 25491 million dollars against all odds [3]. The RMG sector accounts for $81 \%$ of the total export earnings of the country and $10 \%$ of the national economy [4]. Bangladesh is now standing just behind the China in export earning rankings. Bangladesh is the largest exporter of cotton t-shirts and second largest exporter of cotton pullover and jeans for the European Union and the second largest exporter of cotton trousers to the U.S. by volume [5]. The industry has contributed to export earnings, foreign exchange earnings, employment generation, poverty alleviation and the empowerment of women. At present, there are 6000 garment factories [6] in the country employing more than four million workers (up to 2012-2013). 85\% of the labour force are women from low-income families. The sector also contributes to the $17 \%$ GDP (Gross domestic product) [7] in significantly. Bangladesh today is considered as an economic competitor in terms of international garment manufacturing by the other countries. It appears much of the socio-economic development in the first decade of the twenty-first century in Bangladesh and its approximately 1.5 million women workers depend on the continuing success of the RMG 
industry [8]. The RMG factories are located mainly in the four main cities: the capital city Dhaka, the port city Chittagong and the industrial city Narayangonj and Gazipur. RMG factories in Bangladesh vary in size, based on Bangladesh Garment Manufacturers and Exporters Association (BGMEA) [9].

\section{Objectives of the Study}

Objectives of this study can be divided into two parts: the main objective of the study is to identify the causes of industrial disputes in the RMG sector at present. The second objective of the study is to suggest the concerned authority to follow the suggestions provided in the study and further the study urges to take the proper step to curb the industrial disputes in this regard where we can achieve the dream to earn 50 billion dollars at the end of 2021 as well as enriching the national economy.

\section{Methodology}

The study is based on both primary and secondary sources of data i.e. statute, enactment such as the Bangladesh Labour Act, 2006, website of BGMEA, BKMEA, and Bangladesh Institute of Labour Studies (BILS) have been used as primary sources, whereas secondary sources like books, internet articles, newspaper, journals, published thesis, dissertation, different websites, various official and unofficial sources etc. The study is mixed with qualitative, quantitative method and focus group discussion.

\section{Manufactures of Ready-Made Garments}

Bangladesh exports 35 types of garment products in 31 countries around the world. RMG products manufactured in Bangladesh are divided mainly into two broad categories: woven and knit products. Shirts, t-shirts and trousers are the main woven products and undergarments, socks, stockings, tshirts, sweaters and other casual and soft garments are the main knit products. Woven garment products still dominate the garment export earnings of the country. The share of knit garment products has increased since the early 1990's. These products currently account more than 40 percent of the country's total RMG export earnings. Though various types of garments are manufactured in the country, only a few categories, such as shirts, t-shirts, trousers, jackets and sweaters, constitute the major production share [10]. In 2005, the quota restrictions for Bangladesh has withdrawn. Some economists thought, imposing quota restrictions before 2005, it would be a great shock for the garment industry. But in reality, Bangladesh has faced this challenge with great courage. The fact is that the export of garment products has increased after the withdrawn of this quota and the last two years were really good time for garment industry of Bangladesh.

\section{Historical Background of RMG Industry in Bangladesh}

The history of Bangladeshi cloth is old, but in 1980's decade the apparel industry of Bangladesh started its journey. The name late Nurool Quader Khan remembered as the pioneer in the field. In 1978, he sent 120 members to receive training from South Korea. With the help of these skilled, trained workers, he established the first factory - Desh Garments - to produce garments for export. At the same time, the late Akhter Mohammad Musa of Bond Garments, the late Mohammad Reazuddin of Reaz Garments, Md Humayun of Paris Garments, Engineer Mohammad Fazlul Azim of Azim Group, Major (Retd) Abdul Mannan of Sunman Group, M Shamsur Rahman of Stylecraft Limited, the first President of BGMEA, AM Subid Ali of Aristocrat Limited also took steps forward and set up garment factories in Bangladesh. Following them, other hardworking entrepreneurs established RMG factories in the country. Since that time, RMG industry in Bangladesh did not require to look behind. In spite of having many difficulties faced the sector, it has paved its path and possessed maximum world market and kept continuing to show robust performance [11]. In terms of industrialization, the garment industry is a promising sector to contribute national economy. The industry creates the opportunity of employment for millions of unemployed, especially a large number of uneducated women of the country. Once the cloth of Muslin and Jamdani of Bangladesh achieved its worldwide acceptance for its quality and was used as the luxurious garments for the royal and elite figures in Europe and other countries. The British rulers in India did not develop the cloth industries at all, rather they ignored it and imported cloths from England. In the early sixties, individual tailors made garments as per the orders provided by the customers who supplied the fabrics. The sector has rapidly attained high importance in terms of employment, foreign exchange earnings, increasing industrializations in the country. As a result, the sector contributes to the national GDP significantly. The most important factor is, the growth of RMG sector produced a group of young and energetic entrepreneurs who have created a strong private sector. Of these entrepreneurs, a few numbers of females involved them in the sector; a woman entrepreneur came forward and established one of the oldest export-oriented garment factories, named Baishakhi Garment in 1977. At present, many women posseses high official executive post in the RMG industry. In 1978, there were only 9 export-oriented garment manufacturing units, and they generated export earnings which amounted to hardly one million dollars. Some of these units were very small and produced garments for both domestic and export markets. Reaz Garments, Paris Garments, Jewel Garments and Baishakhi Garments were such small units who exported less than one million dollar. Reaz Garments, one of the oldest industries, was established in 1960 as a small tailoring outfit, named "Reaz Store" in Dhaka. In the earliest moment of its establishment, it served only domestic markets for 15 years. 
In 1973, it changed its name to M/s Reaz Garments Ltd. and enhanced its activities into export market by selling 10,000 pieces of men's shirts worth at French Franc 13 million to a Paris-based firm in 1978. The garment Desh had technical and marketing collaboration with the Daewoo Corporation of South Korea. It was also the first hundred percent exportoriented company. It had about 120 operators, including 3 women trained from South Korea, and with these trained workers it commenced its production in early 1980. Another South Korean firm, Young Ones Corporation formed as the first equity joint-venture garment factory with a Bangladeshi firm, Trexim Ltd. in 1980. Bangladeshi partners contributed $51 \%$ of the equity in the new firm, named Young Ones in Bangladesh. It exported its first consignment of padded and non-padded jackets to Sweden in December 1980 [12]. In 1974, Multi- Fiber Agreement (MFA) was signed to control the quantity of imported RMG products from developing countries to developed countries. The agreement imposed an export rate of 6 percent increase every year from a developing country to a developed country. It also permitted to the developed countries to impose quotas on the countries that exported at a higher rate than the rule stipulated in the bilateral agreements. In facing such restrictions, producers started searching for countries that were outside the umbrella of quotas and had cheap labour. This is happening when Bangladesh started to invest in the RMG sector [13].

\section{Causes of Industrial Disputes in RMG Sector}

The socio-economic environment of a labour force of RMG industry in Bangladesh can be said better. Most of the labours are uneducated and unskilled, they get very minimum salary in contrast to the ever-increasing expense of livelihood. Very often they do not get their salary, bonus and overtime bills, and other facilities in time. In many factories, they are forced to work extended hours in unhygienic condition. Misbehaviour and unfair etiquette by the mid-level officers are their common conductivity. It is true that they are not part of anybody in respect of decision making or law making process. In such crucial condition being hopeless, they raise their voice against the unfair practices of the authority and involve themselves in the subversive activites. In spite of having a significant development of the national economy, labour unrest in RMG sector is undermining all its credit [14]. The study focuses on some of the reasons are outlined below.

\subsection{Gender Discrimination}

A large number of female workers of the total labours are engaged in the garment industry. Most of the female workers are involved with the sewing section, while almost all those on the cutting, ironing and finishing sections are operated by men. Women workers are also involved in a variety of occupations from cutting, sewing, inserting buttons, making buttonholes, checking, cleaning the threads, ironing, folding, packing etc. Women work in the garment factory mainly as helpers. There are no female cutting masters. Men dominate the administrative and management level jobs. Women are discriminated in respect of access to higher-paid official post and management positions [15].

\subsection{Lower Wages}

In every year, there are numerous labour disputes occurring throughout the country. Most of the labour disputes originate relating to wages, salary, safety, security, gratuity, provident fund, bargaining compensation for losing parts of the body. Labours deserve a higher pay and better livelihood considering the profit of manufacture of the manufacturers. Unfortunately, the manufacturers do not take unrest as a matter of priority. The most obvious reason for the unrest is the poor scale of wages and increments up to a standard level, which could help them to live a minimum living standard. Providing compensation to the injured worker is guaranteed by the statute, but in practice, the RMG companies do not provide the same as per law. As a result, it creates a situation of unrest in the RMG factories. Due to the labour unrest, the industry incurred a huge loss of production. On account of unrest in some factories, several labours are killed, injured and arrested. Very recently the workers in Tuba Garment were gone on hunger strike for 14 days (July28-11 ${ }^{\text {th }}$ Aug, 2015), demanded their unpaid salaries (including bonus), which were not paid for 3 months. During the period of strike, police crackdown like clubbed, rubber bullets, tear gas, beaten brutally using the stick to disperse the strike while they demanded their reasonable claim. After 14 days of the consecutive strike, the authority of Tuba group paid their three months salary and overtime bills although the rest of the demands were not fulfilled till to date [16]. The demand of the labours or labour unions were to raise their monthly wages from Tk.1600 (US\$ 25) to Tk.5300 (US\$ 70) which has been effective from $5^{\text {th }}$ December of 2013 and is not sufficient still according to the present social structure [17]. In fact, the high inflation of food prices and other necessary commodities, it is getting more difficult for workers to live at the present lowest monthly wage of Tk.5300. Most of the owners of the RMG factories can realise the reality, but they are reluctant to pay necessary facilities to the worker. It is also true that some factories are not obtaining much a high profit to meet their demands.

\subsection{Labour Cost}

In Bangladesh the workers of RMG garments have been paid the cheapest unit labour cost in South Asia. It is a matter of sorrow that it pays only 11 cents to produce a shirt in Bangladesh, whereas it costs 79 cents in Srilanka and 26 cents in India [18]. Thus, it is crystal clear that the workers of Bangladesh are getting cheap labour cost comparing with others, but they deserve a higher pay for their work in matching with the present condition of the international market.

\subsection{Working Hours}

It is very discriminate to the workers that the working 
hours are very long although their wages so minimum. Sometimes they are compelled to work for the extra time despite consecutive work, but it is also a matter of sorrow that they do not get their extra allowance for overtime. The working hours of adult workers in any establishment are described in sections 100-102 of the Bangladesh Labour Act, 2006. In section 100, it is allowed for more than eight hours but not exceeding 10 hours in a day [19]. According to the section 108 of the Bangladesh Labour Act, 2006, where a worker works in any establishment for more than the prescribed hours in any day or in any week under this Act, he shall in respect of overtime work, be entitled to allowance at the rate of twice of the average of his basic wages [20].

\subsection{Safety Problems and No Promotion Opportunity}

It is one of the basic requirements to ensure safety for the workers while they are working in the industries. As the garment owners are neglecting this matter continuously, that's why different types of accidents have been occurring in every year throughout the country. A big example of the incident is Tazreen Fashion garment where a horrific fire broke out on 23 November 2012, consequently more than one hundred workers along with the factory turned into ashes. Poverty drives them to work in an apparently unsafe working environment, risking their lives to ensure the bare minimum for their family. In the end, life is the ultimate price that they paid for undertaking this risk. But until their death, they contributed more than they were paid. [21] Beside this, in the garment sector of Bangladesh, promotion is a rare case. Workers are working in the same position for a long period of time. They also reluctant to switch the company because of the risk of losing one month salary that sometimes leads to labour dispute.

\subsection{No Responsible Organization}

There are so many registered Trade Unions [22] and CBA (Collective Bargaining Agent) [23] working in Bangladesh. But their activities are not satisfactory regarding raising industrial disputes [24] and to the settlement with respect to that dispute [25] in an amicable way, rather the trade unions play an ineffective and inactive role for their own interest, which ultimately results dispute.

\subsection{Sudden Shut Down of Factory}

Due to stoppage of work [26], lay off, [27] or lock out, [28] illegal strike [29], the factory may be closed. Therefore, loss of job, payments and other benefits, labour unrest may happen.

\subsection{Uncertainty of Getting Compensation}

Another reason can be identified the uncertainty of getting compensation. Factory building collapse, fire-accident, stampedes render many dead and injured. Section 150 of the Bangladesh Labour Act has been stated that the employer of any establishment covered under this Act, is required to compensate an employee in following grounds:
Who has suffered an accident arising out of and in the course of his employment, resulting into i) death, ii) permanent total disablement iii) permanent partial disablement or iv) temporary disablement whether total or partial or $[30]$.....

When the workers do not get any compensation as per law, then it turns into labour unrest.

\subsection{Coercive Role of Law-Enforcing Agencies}

The law enforcement agencies are called as the protector of the citizen, but they sometimes played role reverse and took the enmity character against the workers which angers the labours. A common picture is seen at the time of dispute is that the deployed police beating workers brutally and behave inhumanly with the workers and the agitating workers reiterates causing injuries to both sides. Filing cases or arresting the agitating workers while they show their grievance and protest against the law enforcing agencies. Nevertheless, the law enforcing agencies are often found to play a biased role against the workers. As the owners are rich and influential, there is hardly any instance of their arrest [31].

\section{Some Reported Incidents Relating to the Industrial Disputes in RMG Factories}

The RMG factories have a glorious image in terms of contributing GDP, the national economy, women empowers, huge employment, minimizing child marriage, increasing revenue and others. Due to industrial disputes, the sector sometimes falls in trouble and also accounts huge loss and damages. Some reported incidents regarding the issue have outlined below:

Workers of government oriented jute mills, demonstrated their agony and called a hunger strike in Dhaka on 29 January 2006 in support of their Ten Point demands [32]. In January 2006, Bondhokrito Adamjee Jute Mills Ltd. Krishok o Khudra Pat Byaboyshayee Paonadar Samity (Association of Peasants and Small Traders of the shutdown Adamjee Jute Mills) had blocked Dhaka's main commercial area for an hour [33]. During May 2006 to June 2006, labour disputes were held on some RMG factories. At that time of unrest, nearly 1.8 million workers were participating. Workers of more than 4000 of RMG factories were showed their demonstration and repercussion during the $3^{\text {rd }}$ week of May 2006 [34]. A report of the "Bangladesh Institute of Labour Studies" that in the $1^{\text {st }}$ six months of 2012 , labour disputes have been held throughout the country. The sector also experienced serious unrests during mid-july in 2010. Worker unrest also occurred in 2010 for materializing minimum wages of US $\$ 70$ per month. In such unrest, two hundred workers were injured and thirty factories were ransacked [35]. Very recently the workers of Tuba Garment were gone on hunger strike for 11 days (July-28-10 ${ }^{\text {th }}$ Aug, 2015) on account of demanding their unpaid salaries and bonus [36]. 


\section{Consequences of Labour Dispute}

The impact of industrial disputes in RMG is an irreparable loss with respect to the country's economy, which is not only broken down the growth of magnificent ratio but also creates negative impact on the workers and owners whether it amounts to the rapid growth of the total industrialization in catastrophic. All the four parties- the workers, the owners, government and foreign buyers will be affected. If industrial disputes continue, the foreign buyers will disagree to purchase, invest and cancel their orders and divert to other exporters like India, China or Cambodia. Thousands of RMG factories will be shut down, workers become unemployment and they will be involved in unsocial or criminal activities. The government will be deprived of a huge income source in respect of foreign exchange and revenue. The industrialization development process of the country will be interrupted. A huge number of businesses, grown based on RMG industry, will suffer. The entire economy of Bangladesh would be adversely affected [37]. Consequently, this industry will be ruined like the jute industry where once upon a time it was called as "Golden Fiber of Bangladesh".

\section{Some Proposals Towards Resolving the Industrial Disputes}

According to the above discussion the study proposes some recommendations to resolve the RMG disputes:

\subsection{Better Working Environment}

It is true, but unfortunate that most of the factories are failing to provide and maintain a hygienic working atmosphere. If the owners follow the instruction as per labour law and provide healthy and safe environment it will free them affecting virulent diseases as well as mental stress.

\subsection{Removing Gender Discrimination}

Most of the labour women's in RMG sector are working in the lower grade post such as sewing, cutting, finishing, etc. In Bangladesh maximum labour force is coming from women. It is also true that most of the women are from rural, uneducated and unskilled. Realizing the fact there should be a step for those who are working for more than 3-4 years, they would be promoted to the upper position.

\subsection{Payment of Wages Without Any Delay}

The prime reason of the industrial dispute is originated from delay payment or non-payment of wages, bonus, compensation, etc. Where the country's economy and GDP's increasing with the aid of RMG source, but it is regrettable matter is that labours of RMG are getting lower wages which are not matching with the present life standard. Though the government took the initiative to increase the wages up to $5300 \mathrm{tk}$, it is not sufficient according to present market status. Alongside some garment owners are reluctant to pay wages, bonus, overtime, or compensation in case of injury. Thus, the government needs to take the strong policy to resolve the issue such as penalizing or attaching the property of the owners who do not pay or making delay.

\subsection{Training for Unskilled Labour}

In order to make a skilled worker and to protect the garment industry from industrial disputes it is needed to train the workers for the period of 7-10 days on 6 months basis for various issues such as handling the machines, mannerism, self- protection from fire accident and other natural disasters.

\subsection{Increasing Labour Cost}

Compared with the other countries the workers of Bangladesh deserve a high unit labour cost. Thus, the unit labour cost should be increased like other developed countries.

\subsection{Overtime Benefit Should Be Paid Without Delay}

Another reason for industrial dispute is workers are not getting the overtime bill in timely. Sometimes RMG owners make unreasonable delay to pay the overtime bill to the workers. Thus, a provision should be inserted for paying overtime bill that the workers will recieve the bill in first three days of the next week for extra hours work for the previous week.

\subsection{Removing Internal Influences, Pressure from Local Mastans and Terrorists}

The government should take an initiative in order to removing internal influences, local mastans and terrorists ordering law enforcing agencies that they should be arrested after committing the occurrence showing zero tolerance for their misdeeds.

\subsection{Creating Promotion Opportunity}

It is another disappointed matter is that the garment workers are working on the same post for 5-6 years, but the authority does not provide any promotion for their performances. So it is urged to the BGMEA and BKMEA to take the matter into consideration and put the pressure on the garment owners creating promotion opportunity in this regard.

\subsection{Responsible Organisation}

Some leaders of trade unions or CBA are not cordial to raise the industrial dispute as per law. Sometimes they do not take the matter into consideration for their own interest rather they maintain a hidden link with the owners of the factory. Thus, BGMEA and BKMEA constitute a separate body to probe the matter in this regard. If it is proved that they maintain connectivity with owners for their personal gain, they must be brought in judicial action and the registration of the trade union should be cancelled.

\subsection{ADR Formula Should Be Applied}

Section 210 has been inscribed in the existing Labour Act, 
2006 applying ADR to resolve the industrial disputes between workers and owner. The section is inadequate and insufficient to remove disputes and oust chaos from the grass root level. Thus, in the Bangladesh Labour (Amendment) Act, 2013, section 124A has also been incorporated. Though the ADR formula seldom exercises in the RMG sector, rather, it depends upon the arbitrary decision of the owner. Despite having the infrastructural lacuna in regard to the present ADR system in the Bangladesh Labour Act, 2006 and The Bangladesh Labour (Amendment) Act 2013, the study suggests following the other countries to mitigate the unexpected situation. It may reduce the rate of numerous industrial disputes throughout the country.

\section{Conclusion}

In a very recent meeting on $10 / 11 / 14$, the secretary general John Danilovich of the International Chamber of Commerce (ICC) has said: "Bangladesh is a model country for the rest of the world thanks to its resilience and the continuous economic growth in the face of crisis". He further observed, "Bangladesh is no longer a test case for development, if Bangladesh can develop, any country could [38]. From his statement, it indicates that the sector is a shoreless possibility in terms of the national economy and huge employment. The industry is now dreaming to export US 50 billion dollars at the end of 2021 [39]. It should be kept in mind that for sustaining and keeping the economic strength and growth sincerity and prompt action from government to minimize the disputes, sympathetic attitude and maintaining friendship behaviour towards labour, active step from CBA and trade unions resolve labour disputes from the RMG industry. The success of ratio of resolving disputes would be magnificent if the government and concerned authority would be sincere and cordial to remove the shortcomings of ADR and inspiring worker and owner to proceed forward with the ADR system. The only framing of enactment does not change the chaotic condition or reduce the overload cases. It needs proper amendment of the existing provisions, framing more effective regulations where it is necessary and urgent, also required the trust and getting back reliance of the people. The authority should inspire the parties to the disputes, growing awareness, consciousness, increasing publicity, minimizing the problems of ADR, and to set up a good infrastructure so that the justice seeker can get a remedy in cheaper and easier ways to a win -win situation. Then it will establish peace and unity at all levels of the guild specially the poor and disadvantaged, backwards people will get fair and equitable justice as it has been given guarantee in the supreme law of the land. To keep the growth sustain, ensuring quality facilities, increasing production capacity, orchestrating working ambience, to overcome the economic catastrophic, ensuring laxity on law and order situation, and strengthening the entire chain, only a friendship relation between labour and owners can remove a maximum number of labour disputes from the RMG sector.

\section{References}

[1] About Garment Industry of Bangladesh, please see at: http://www.bgmea.com.bd/ home/ about/About GarmentsIndustry, last accessed on: 12/10/15.

[2] Bangladesh Ranks $4^{\text {th }}$ largest clothing Exporter In World, also available at: http://en.people.cn/90001/90777/90851/7077466.html last accessed on: 12/08/16.

[3] Ibid.

[4] Made In Bangladesh With Pride, please see at: http://www.bgmea.com.bd/blog/story/

[5] Supra note 2, para no-4.

[6] Factory Growth In BD, also available at: http://www.bgmea.com.bd/chart_test/ factory_growth_in_bangladesh

[7] Hossain, Md. Noor, Contribution of Textile and RMG Sector in Bangladesh Economy, please see at: http://textilelearner.blogspot.com/2014/07/contribution-oftextile-rmg-sector-in.html

[8] Problems of Garment Industry In Bangladesh also available at:

http://conveylive.com/a/Problems_of_Read_Made_Garments Sector_In_Bangladesh

[9] Problems and Prospects of Ready Made Garments Export In Bangladesh, also available at:http://www.assignmentpoint.com/science/textile/problemsprospects-readymade-garments-export-bangladesh.html

[10] Present Condition/Situation of Ready Made Garments Industry in Bangladesh, available at: http://textilelearner.blogspot.com/2012/11/presentconditionsituation-of-ready.html

[11] Hassan, Faruque, RMG industry of Bangladesh: Past, Present and Future, please see at: http://www.dhakatribune.com/longform/2014/sep/16/rmg-industry-bangladesh-past-present-andfuture, accessed on: 18/10/15.

[12] Sarkar, Md. Fouad Hossain, History of Garment Industry In Bangladesh, also available at: http://forum.daffodilvarsity.edu.bd/index.php?topic=4706.0

[13] Acknowledgement Garments in Bangladesh, also available at: http://garments acknowledgement.blogspot.com/ 2012/01/ in1950s-labours-in-western-world-became.html

[14] Khan, Mohammad Aminul Islam, Labour Unrest in the RMG Sector of Bangladesh: A Public Private Cooperation Perspective, also available at: http://www.mppgnsu.org/attachments/339_Aminul\%20Islam $\% 20$ Khan.pdf

[15] Problems of Garments Industry in Bangladesh - also available at:

http://conveylive.com/a/Problems_Of_Read_Made_Garments _Sector_In_Bangladesh Accessed on: 21/07/15.

[16] Police Crack down on Unpaid Tuba garment workers, also available http://bdnews24.com/bangladesh/2014/08/08/police-crackdown-on-unpaid-tuba-garment-workers, accessed on: 21/07/15. 
[17] Wage Range: Minimum tk. 5300 and maximum $t k$, 6850, also available at: http://news.priyo.com/2013/11/22/wage-rangeminimum-tk-5300-maximum-tk-6850-92175.html. Accessed on $21 / 07 / 15$.

[18] Supra note 17.

[19] Section 100 of the Bangladesh Labour Act, 2006.

[20] Section 108 of the Bangladesh Labour Act, 2006.

[21] Tazreen Trazedy: At Stake is the RMG Sector, please see at: http://www.thefinancialexpress-bd.com/old/index. Accessed on $22 / 07 / 15$.

[22] Section 2 (15) of the Bangladesh Labour Act, 2006 states that, Trade Union means trade union of workers or employers registered and constituted under chapter thirteen of this Act.

[23] Section 2 (52) of the Bangladesh Labour Act, 2006, has been stated that, Collective Bargaining Agent, in relation to an establishment or group of establishments, means the trade union or federation of trade unions which under chapter thirteen, is the agent (CBA) of the worker in the establishment or, as the case may be, in the group of establishments in the matter of collective bargaining.

[24] Section 209 of the Bangladesh Labour Act, 2006, stipulates that, No industrial dispute shall be deemed to exist unless it has been raised by an employer or a collective bargaining agent in accordance with the provisions.

[25] Section 210 of the Bangladesh Labour Act, 2006.

[26] Section 12 (1) of the Bangladesh Labour Act, 2006, the employer may, at any time, in the event of fire, catastrophe breakdown of machinery, or stoppage of power supply, epidemics, civil commotions, or other cause beyond his control, stop any section or sections of the establishment, wholly or partly, and for the period of stoppage will be as long as the reason for which the stoppage was declared continues.

[27] Section 2 (58) of the Bangladesh Labour Act, 2006, states that, means the failure, refusal, or inability of an employer on account of shortage of coal, power or raw material, or the accumulation of stock, or the breakdown of machinery, to give employment of a worker.

[28] Section 2 (57) of the Bangladesh Labour Act, 2006, has been laid that lock out means the closing of a place of employment or part of such place, or the suspension, wholly or partly, of work by an employer, or refusal, absolute or conditional, by an employer to continue to (work) any number of worker employed by him, where such closing, suspension or refusal occurs in connection with an industrial dispute or is intended for the purpose of compelling workmen employed to accept certain terms and conditions of or affecting employment.

[29] Section 2 (44) of the Bangladesh Labour Act, 2006, has been stated that Illegal Strike means a strike declared commenced or continued (by violating) the provisions of Chapter Fourteen of this Act.

[30] Ahmed, Zulfiquar, A Text Book of the Bangladesh Labour Act 2006, $8^{\text {th }}$ edition, Shams Publications, Dhaka, 2014.
[31] Supra note 17, p-35.

[32] Government to mull over textile and jute worker's demands, February 3, 2006, also available at: http://www.fibre2fashion.com/news/textilenews/newsdetails.a spx?news_id $=12110$

[33] Islam, Soma, Workers' Rights, please see at: $\mathrm{http}: / / \mathrm{www}$.askbd.org/ask/workers-rights

[34] Tamanna, Urmi, Labour Unrest in Bangladesh RMG Sector: Does Active Labour Union Reduce the Risk of Labour Unrest in $R M G$ Sector? Also available at: http://dspace.bracu.ac.bd/bitstream/handle/10361/2087/Labour \%20Unrest\%20in\%20Bangladesh\%20RMG\%20Sector.pdf?

[35] Ahmed, Shaheen, Raihan, Mohammad, Zaheer, and Islam, Nazrul, Labour Unrest in the Ready Made Garment Industry of Bangladesh, please see at: http://www.ccsenet.org/journal/index.php/ijbm/article/viewFil e.

[36] Police Crack Down on Unpaid Tuba Garment Workers, also available http://bdnews24.com/bangladesh/2014/08/08/police-crackdown-on-unpaid-tuba-garment-workers

[37] Supra note $17 \mathrm{p}-36$.

[38] Bangladesh is a growth model for its resilience, please see at: http://www.thedailystar.net/bangladesh-is-a-growth-modelfor-its-resilience.

[39] Faruk, Mohammad, Omar, Making Dream of $\$ 50$ million dollars RMG Export Come True by 2021, also available at: http://www.hawker.com.bd/news_details.php?news_id.

\section{Biography}

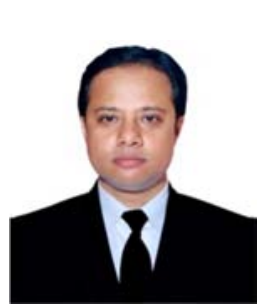

Mohammad Monir Hossen is currently working as an Assistant Professor under the Department of Law at the Z.H. Sikder University of Science and Technology. He received his LL.B. (Honor's) and LL.M. degree from the University of Chittagong. Now he has been registered in the Ph.D. program under the University of Dhaka.

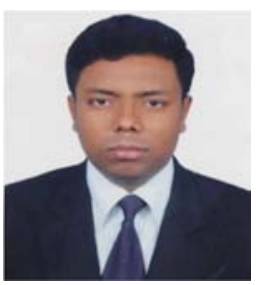

Md Hossen Miazee is currently working as a Lecturer under the Department of Business Studies at the University of Information Technology \& Sciences. He received his Bachelor of Commerce (Honor's) and Master of Commerce with major in Accounting from Jagannath University, Bangladesh. He also achieved Master of Business Administration with major in Marketing and Management from Mid Sweden University, Sweden. 